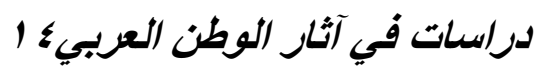

\title{
The Stela of Nebet-Kebeny CG 34117
}

\section{Dr. Maha Yehia}

\section{Introduction}

This stela of Nebet-Kebeny ${ }^{1}$ was found at Abydos and is kept now in Cairo Museum CG 34117. ${ }^{2}$ The stela is made of fine white limestone. It is finely carved, round-topped and measures $66.5 \mathrm{x} 41$ $\mathrm{cm}$. The subject matter of the text inscribed on the document under discussion is overwhelmingly dominated by the funerary offering formula addressed to the gods of the west and the high religious titles of the owner family members ${ }^{3}$.

The stela is to be considered a funerary where Wepwawet and Anubis in the form of two jackals stretched on their plinth facing each other figure, both labelled Wepwawet lord of Abydos and Anubis lord of the west.

\section{Description:}

The stela CG 34117 (Fig. 1) is divided into four parts ${ }^{4}$ : The upper part is the protection symbol, the second part is the first scene, the third part is the second scene, and the fourth is the main text.

\footnotetext{
- faculty of the tourism and hotels.

${ }^{1}$ Ranke, H. (1935) Die altägyptischen Personennamen I-III 189 (17) Glückstadt/Hamburg/New York: J.J. Augustin,. Discuss the name of $K 3$ bnj

${ }^{2}$ I am so grateful to the authorities of Cairo Museum for allowing me to study and publish this stela.
}

${ }^{3}$ This stela comes from Abydos, northern necropolis. The Owner of this stela may have been resident at Thebes. Egyptian officials in dynastic times are well known for their extensive travels on royal missions, many having served in both extremes, the far north and Nubia and the Sudan. see: Tosi, M. Roccati, A. (1972) Stele e alter epigraphi di Deir el Medina, 345, N. 50225, Turin.

${ }^{4}$ It is well known that the innumerable private stelae of the New Kingdom are either roundtopped or pyramidion. see, Černy, J. (1958) Egyptian Stelae in Bankes collection, Oxford. See also, Gaballa, A. (1979) three funerary stelae from New Kingdom; in: Mitteilungen des Deutschen Archäologischen Instituts Abteilung Kairo 35, pp. 189- 194; id, (1979) false-door stelae of some Memphite personnel, in: Studien zur Altägyptischen Kultur 7, pp.41-52; Radwan, A. ( 1987) Six Ramesside Stelae in Popular Pyramidion form. In: Annales du service des antiquités de I'Égypte 71, p. 223 ff; For some earlier studies, see; Klebs, L. (1934) Die Reliefs und Malereien des neuen Reiches, Abhandlungen der Heidelberger 
Each part will be separately discussed to shed light on the contents (scenes and texts) of the stela.

Round-topped stela, somewhat irregularly cut, the lunette of the stela is sign of water $\operatorname{mm} m w$ - these elements being flanked by a pair of eyes of Horus criteria clearly date the stela in the eighteenth dynasty. The lunette reliefs are occurred in bas relief, and the text is incised relief

The upper part:

Under the lunette there are two couchant jackals in the $\operatorname{arch} 5$ s 5 : Anubis at right and Wepwawet of the south at left ${ }^{5}$. The following text appears behind the left figure, the text is written from right to left:

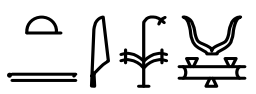

Akademie der Wissenschaften, Philosophisch-Historische Klasse, 177- 178, Heidelberg, Winter; Junker, H. Giza XI, 186; Goedicke, H. (1958) Ein Verehrer des Weisen Dd.f hr aus dem späten Alten Reich in: Annales du service des antiquités de I'Égypte 55, 45-49; Dominicus, B. (1994) Gesten und Gebärden in Darstellungen des Alten und Mittleren Reiches, Studien zur Archäologie und Geschichte Altägyptens 10, pp. 28-32; EL-Khadragy, M. The adoration gesture in private tombs up to the early Middle Kingdom in Studien zur Altägyptischen Kultur 29 pp.189-201. In the Old Kingdom and Middle Kingdom more documents of the adoration attitude were known, see also; Dunham, D. (1937) Naga-ed-Der Stela of the first Intermediate Period, 178, London; Goedicke, H. (1958) in: Annales du service des antiquités de I'Égypte 55, 45-49; In the Old Kingdom and Middle Kingdom more documents of the also for Parallel to our document but not identical, see; EL-Saady, H. (1995) Two Heliopolitan Stela of the New Kingdom, in Zeitschrift für Ägyptische Sprache und Altertumskunde, 122, pp. 101 ff; Eisa, A. (1994) Zwei Votivstelen eines Beamten namens Parenacht aus Siute. In: Studien zur Altägyptischen Kultur 21, , pp. 59 ff; Simpson, W.K. (1974)The Terrace of the great God at Abydos, 4 ff; Petersen, B. (1969) Aegytische Stelen und Stelenfragmente aus stockholmer Sammlungen, pp. 95ff.

${ }^{5}$ On the frequent epithets of the both gods (Wepwawat \& Anubis ) see; Dakin, A. N. (1938) The Stela of the Sculptor Sire at Oxford, in: Journal of Egyptian Archaeology 24, p. 192, pl. 1; Eissa, A. (1989) Untersuchungen zum Gott Upuaut bis zum Ende des Neuen Reiches (Unpublished thesis, University of Cairo 1989); Eissa, A. (1994) Zwei Votivstelen eines Beamten namens Parènacht aus Siût in: Studien zur Altägyptischen Kultur 21, p. 59 ff. note 1; Munro, P. (1962) Einige Votivstelen an Wp w3wt, in: Zeitschrift für Ägyptische Sprache und Altertumskunde 88, 48 ff; H. Brunner, in: Mitteilungen des Deutschen Archäologischen Instituts Abteilung Kairo 16, 1958, 5ff. 


\section{دراسات في آثار الوطن العربيء 1}

$$
W p-w 3 . w t . t
$$

$W p w 3 w t \check{s} m^{\ulcorner} y t$

Wepwawet of Upper Egypt.

Behind the right figure of Anubis the text read, the text is written from left to right:

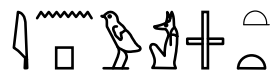

Inpw imyn-tt

Anubis of the West.

The second part

The first scene or the main scene at the left side representing the owner of the stela Nbt k3bny sitting and suckling a female-child, her name is above her: ś3.t-Imn Sat-Amun ${ }^{6}$ her name is written inside a Cartouche, the placing of the name in a cartouche confirms a royal status, Sat-Amun is a daughter of Amenhotep III, but there is no evidence that the Sat-Amun of the stela here is the same person. In front of them the son of Nbt K3bny, his name is $h k 3 n f r$ represented wears the leopard skin, and a sandal, his title is written above him "the scribe of the temple of Osiris" he pours a libation on an offering-table ${ }^{7}$ before his mother. Behind him is his wife B3t, standing and raising her right hand with sistrum and carrying $a$ menit, necklace in her left hand. Between them is their son, sitting,

\footnotetext{
${ }^{6}$ Ranke, PN I,286 (7); this name was mentioned on the two stelae of the overseer of Goldworkers of Amun, Amunemhab, at Yale and the oriental institute, see; Simpson, W. (1979) two stelae of the overseer of Goldworkers of Amun, Amunemhab, at Yale and the oriental institute, in: Bulletin of the Egyptological Seminar I, pp. 47-54, p. 49 pls,2-3.; Lange, H. ; Schäfer, H. (1902) Grab- und Denksteine des Mittleren Reichs im Museum von Kairo, Catalogue général des antiquités égyptiennes du Musée du Caire / Service des Antiquités de l'Égypte ; 20001/20780, Berlin.; 1908, No. 20097b; Capart, J. (1900 ) Monument inedit de la collection Ed. Fetis, a Bruxelles. Rec.de.Trav.22 pp. 105-108; s3.t'Imn the "daughter of the god Imn" which attested in the Middle Kingdom in: Lange, H. ; Schäfer, H. op.cit. No 20034.; Bouriant, U. Recueil de cones Funeraires, La Mémoires / publiés par les membres de la Mission Archéologique Française au Caire, 8,2 p. 277, 46; where her name was attested with the name of Amenmhat who is depicted in this stela on the third part as he is the son of NbtK3bny; 281,107. s3t'Imun is the name of the daughter of Amenophis III

7 Blackman, A. (1912) The Significance of Incense and Libations' in: Zeitschrift für Ägyptische Sprache und Altertumskunde 50, 69-75.
} 


\section{دراسات في آثار الوطن العربيء 1}

putting his right hand to the chest, his name is written above him:

?

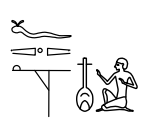

s3.f mn.w nfr his son Mnw-nfr "Min is good". 8

The following text appears above the figure of the wife who is standing at the right side of the first scene, the hieroglyphs is written from top to bottom and facing left:

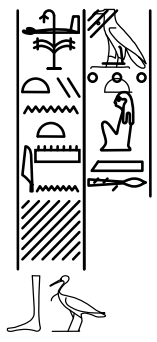

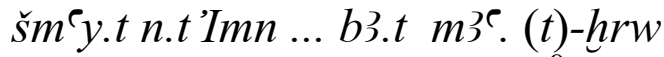

The singer of Amun ...-Bat ${ }^{9}$ the venerated.

Above the seated figure of Nbt k3bny the owner of the stela and the female-child $s 3 t$ 3mun who is sitting on her lap, the text is depicted in vertical lines. The text which above the female-child is written facing left like the female-child's face and that of Nbt k3bny the owner of the stela is facing right like the face of $N b t k 3 b n y$, this system is adopted in all texts on this stela; the hieroglyphic signs are directed to the same direction of the figure which the text describes. Above the seated figures the texts read as follow:

\footnotetext{
${ }^{8}$ Ranke, PN I, 152; the name is attested from the Old Kingdom see Mariette, G., (1890) Les Mastabas de l'ancien empire, Paris, p. 457; in the Middle Kingdom see Petrie, W. (1890) Kahun, Gurob, and Hawara, London, pl. 11,2.; Lange, H.O.; Schäfer, H. (1902) Grab- und Denksteine des Mittleren Reichs im Museum von Kairo, Catalogue général des antiquités égyptiennes du Musée du Caire / Service des Antiquités de l'Égypte ; 20001/20780, Berlin. 1908, No. 20021h, 20131b; and in the New Kingdom see Wb. 187

${ }^{9}$-Ranke, H. PN I, 226 (12).
} 


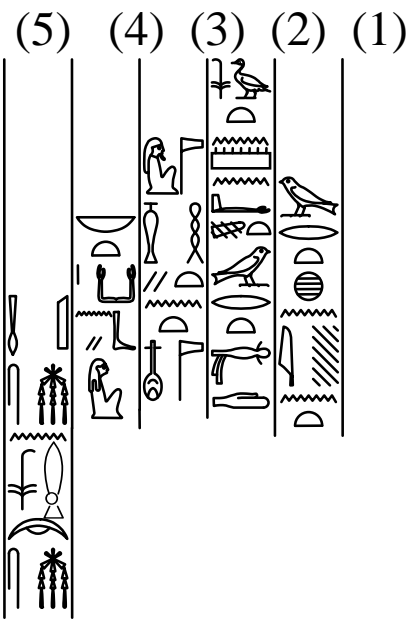

Top (2) s3.t-nsw (1) wr.t hni n.t (above the figure of the femalechild) imn s3.t'Imn (2) $m n^{\top} . t$ wr.t $\check{s} d .(t)$ (3)hs.ti ntr n.t nfr ntr (4) Nb.t-K3bny (5)m3'.t-hrrw ms $n \underline{h} k r-n s w^{10}$ TCh-ms

(2)The great daughter of the king, (1)the musician of Amun (above the figure of the female-child)Satamun, (2) the great foster-mother, the King's nurse, (3) whom the good god praises, (4) Nebet-Kebeny ${ }^{11}$, (5) the venerated, born to the King's adorned one Ieah-mes. ${ }^{12}$

${ }^{10}$ A group of titles which appears quite frequently in connection with the treasury officials is that of $h k r n s w t$. This title is often found in $\underline{h d}, \underline{h k r} n s w t$ appears most frequently in the title imy-r izwy hhkr nzwt. See: Strudwick, N. (1985) The Administration of Egypt in the Old Kingdom the Highest Titles and their Holders. Studies in Egyptology 2, London, p. 283; Ward, W. (1982) Index of Egyptian Administrative and Religious titles of the Middle Kingdom, Beirut, p. 143; Nord, D. hkrt-nswt=King's Concubine?, Serapis 2, p. 1; Drenkhahn, R. (1976) Bemerkungen zu dem Titel $\underline{h} k r . t$ nswt, Studien zur Altägyptischen Kultur 4, pp. 59-67

${ }^{11}$ Ranke, H. PN, I,189 (17)

${ }^{12}$ Ranke, H. ,PN, I, 12 (20) 


\section{دراسات في آثار الوطن العزبيء 1}

At the middle above the figure of the son of Nbt K3bny is the following text:

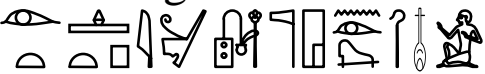

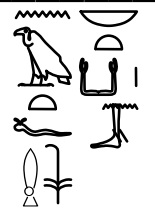

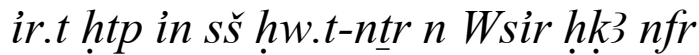
$n$ mw.t ff $h k r-n s w$ Nb.t-K3bny

Making offering by the scribe of the temple of Osiris, Heqanefer, to his mother, the King's nurse, Nebet-Kebeny ${ }^{13}$

The third part:

The third part of the stela has the representation of five figures: at the left side, may be another son of the owner of the stela is representing together with his wife seated on the same high backed chair with a lion feet facing a table of offerings, heaped with the usual offerings and topped by the bundle of lotus, receiving the offerings from a standing figure of a man, may be a son of the owner of the stela. The wife extends her left arm around her husband to clasp her husband on the right upper arm near his shoulder; he extended his right arm hold in it a piece of cloth. Right above them are two short columns of text with their titles and names, and one horizontal line of text.

The use of the available space, the artist has placed their feet and the front leg of the stand on a low pedestal with offering table; as a consequence, the front leg of the chair is shorter than the back leg. The high backed chair with slanting backrest is the type of the second intermediate period and New Kingdom. All figures wear the same broad collar. The lotus blossoms held by men are big and less

\footnotetext{
${ }^{13}$ „lady of Byblos" the name is attested in the Old Kingdom in a tomb in Asswan, Urk. I, 140, see: Sethe, K. (1908) Zur ältesten Geschichte des ägyptischen Seeverkehrs mit Byblos und dem Libanongebiet, Der älteste ägyptische Name von Byblos. In: Zeitschrift für Ägyptische Sprache und Altertumskunde 45, pp. 7-14, p. 9; Erman, A. (1905) Zur ägyptischen Religion. Zeitschrift für Ägyptische Sprache und Altertumskunde 42, pp. 106-110, p. 109.
} 


\section{دراسات في آثار الوطن العربيء 1}

delicately fashioned. In the treatment of the faces, the husband's face shows only a single ear, the wife's ear being appeared from her wig. Some elements such as rich decoration and a considerable vitality are still found in the depiction of plants can be found in Amarna art and was extended as late as the Twentieth Dynasty and possibly even later.

In front of the two seated figures is a figure may be represent the third son of the owner of the stela, behind him is a figure may be the fourth son of the owner of the stela, sitting and holding a lotusflower and behind him is his daughter, sitting and holding a lotusflower. Above them are their complete titles and names ${ }^{14}$.

The lotus-flower upon the offering table, in front of the owner in the first register ${ }^{15}$, the motif of placing the lotus- flower among the offerings appears in the New Kingdom and attained its greatest popularity during that period. ${ }^{16}$

14 The relationship between the persons depicted in this register and the first register is not quite clear.

${ }^{15}$ The Lotus flower on the offering tables comes according to the idea that, the lotus-flower emerges directly from the feet of the god Osiris and the dead person identifies himself with everything, which enshrines the principle of the resurrection, such as the morning star, divine power of gods, as well as the lotus-blossom itself. Then one may assume that it stands here for symbolic reasons divine power of gods, as well as the lotus-blossom itself. See; Griffiths, J. op.cit., pp. 68 ff; Morsi, M. Two Ramesside stelae from Heliopolis, in: Göttinger Miszellen $105,60$.

${ }^{16}$-The Smelling of Lotus-blossom appears frequently on stelae since the end of Amenemhet II's role, see : Berlin 1190 (Amenemhet II, Jahr 23):BM 829(BM Stelae IV, pl.5) (Amnemhat II, Jahr 29): Fisher, H. (1957) A God and a General of the Oasis on a Stela of the Late Middle kingdom in: Journal of Near Eastern Studies 16, p. 224. n. 6. On the motif of the Lotusflower and its connotations of rebirth, see especially: Philippe Derchain, "Le lotus, la mandragore et le persēa,"in: Chronique d'Égypte 50 (1975), pp. 65-86; Malaise, M. (1977) La position de la femme sur le steles du Moyen Empire, in: Studien zur Altägyptischen Kultur 5, pp. 189-191; and Robins, G. (1990) Problems in Interpreting Egyptian Art," DE 17, pp. 50-51; Allen, T.G. (1974) The Book of the Dead, Chicago, p. 70, Chapters 80-81; The smiling of lotus-blossom appears frequently on stelae since the end of the Amenemhat II ( or Senusert III ) The motif certainly goes back to the reign of Pepi II, however, and is not infrequent in the following Intermediate period see: Fisher, H. (1957) op.cit. p. 224. n. 6; see also, Franke, D. (1983) Die Stele inv. Nr. 4403 im Landsmuseum in Oldenburg. in: Studien zur Altägyptischen Kultur 10, pp.158 ff.; Capart, J. (1911) L' Art Egyptien, Brussels, pl. 141, see also: EL-Saady, H. (1995) Two Heliopolitan Stela of the New Kingdom, in Zeitschrift für Ägyptische Sprache und Altertumskunde, 122, p.103; Klebs, L. (1932) Die Reliefs und Malereien des neuen 


\section{دراسات في آثار الوطن العربيء 1}

The text of the third part of the stela is written in columns at the right side is facing left, and that of the text at the left side is depicted in two directions; the text which belong to the man is directed to the right, and that of his wife is directed to the left

$(8)$

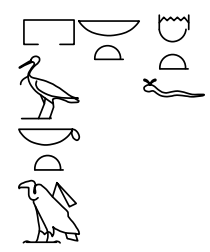

(2)

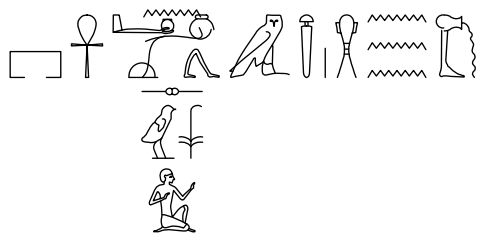

(1)

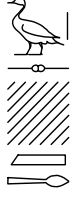

(6)

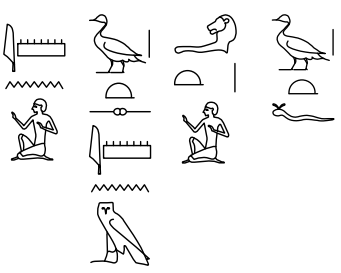

(1) w'b s3 tpj mnk ${ }^{\top} n h^{17}$ (2) ny sy nsw, (3)hm.t f (4) nb.t (5)pr

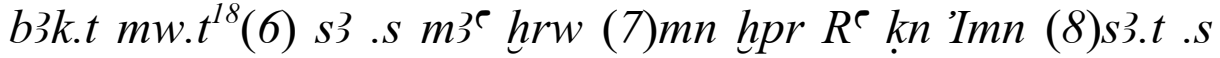
Imn $m$ h $3 t(9)$ s3.t.f $N b$ ntrw ${ }^{19}$

(1)The first lector priest of Menek Ankh (temple of Tutmosis III) (2) Nysy Nesw, (3) his wife (4) the lady (5)of the house Baket Mut. (6)Her son .... the venerated (7)(Mn Kheper Ra) Qen Amun. (8)Her son Imn m Hat and (9) his daughter Nb Netrw

The fourth part contains the main dedication text of the offering formula, which runs from right to left in three horizontal lines ${ }^{20}$

Reiches I., Heidelberg, pp.41 ff; Brunner-Traut: in: LÄ III,pp.1091-1096; Schlögl, H. (1977) Der Sonnengott auf der Blüte, AH 5 , Basel-Genf, passim; Dettmar, J. (1986) Blumen und Blumensräusse als Opfergabe im alten Ägypter, München, pp. 71 ff ;Ryhiner, L. (1986) L'Offrande du Lotus, Bruxelles, pp.177 ff; Vandier, J. (1964) Manuel d,Archeol. Eg. IV, Abb.32. 139, 80 Abb.144 ff, Paris; Altenmüller, H. (1968) Zwei neue Exemplare des Opfertexte der 5. Dynastie in: Mitteilungen des Deutschen Archäologischen Instituts Abteilung Kairo 23, pp.3 -8; see for example scenes of Seti I. offering to Atum or Ramses II: adoring the Theban triad in Karnak temple, In: Nelson, H. (1981) The Great Hypostyle Hall at Karnak, vol. I., Part I, pls. 36, 175, Chicago.

${ }^{17}$ The name of the temple of King Tuthmoses III

${ }^{18}$ Ranke, H. PN I p. 92

${ }^{19}$ Ranke, H. PN 185 

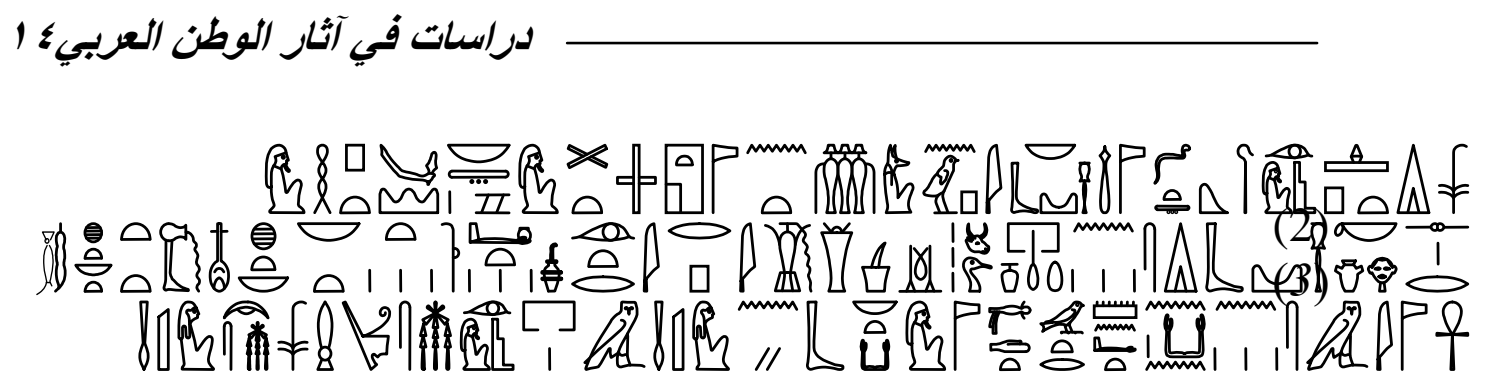

(1) htp di nsw (n) wsir hạ $\underline{\text { d.t }}$ ntr 93 nb 3bdw inpw hnty sh-ntr imy-w.t nb t3-dsr.w Pth-

(2) skr hry-ib 3bdw di.sn pr.t-hrrw (m) t hnk.t k3.w 3pd.w šs mnh.t sntr mrh.t kbh.w irp irt.t hnnk.t rnp.wt nb.(w)t h.t $n b(. t) n f r(. t)$ $w^{\odot} b(. t)$ h.t $n b . t$ ndm.t bnr.t

(3) `nh ntr im.sn $n k 3 n$ mn`.t wr.t šd.t-ntr Nb.t-Kbny m3`.(t)-hrw

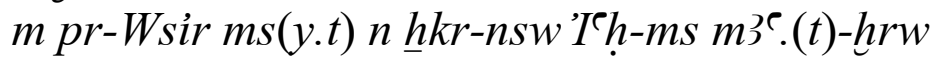

(1)An Offering, which the king gives (to) Osiris, ruler of eternity, the great god, lord of $\operatorname{Abydos}^{21}$, (to) Anubis, who is in front of the god's shrine, he who in the place of embalming, lord of the sacred land (i.e. the Necropolis ), Ptah- (2) Soker, who is in the middle of Abydos (namely) that they may cause an invocation offering to come forth (consisting of) bread, beer, cattle, fowl, alabaster, clothes, incense, oil, jar, wine, milk, beer, all sorts of vegetables, everything good and pure, and every sweet thing (3) on which the god lives for the ka the great foster-mother, the god's nurse Nebet-Kebeny, the venerated, in the house of Osiris, born to the ornamented one of the king 'Th-Mes the venerated. ${ }^{22}$

\footnotetext{
${ }^{20}$ Smither, P. (1939) "The Writing of $h t p-d i-n s w$ in the Middle and New Kingdom" Journal of Egyptian Archaeology 25, 34, see also; Bennet, C. (1941) Growth of the htp-di-nsw formula in the Middle Kingdom" , Journal of Egyptian Archaeology 27, 77; Spanel, D. (1996) “ Paleographic and Epigraphic Distinction Between Texts of the so- called First Intermediate Period and the Early Twelfth Dynasty in : Manuelian, studies in Honor of William Kely Simpson, Vol. II, $769 \mathrm{ff}$, Boston.

${ }^{21}$ For the epithets of Osiris, see: Barta, W. (1968) Aufbau und Bedeutung der altaegyptischen Opferformel, Ägyptologische Forschungen 24, p.15, 25, Augustin; Begelsbacher-Fischer, Barbara L. (1981) Untersuchungen zur Götterwelt das Alten Reiches im Spiegel der Privatgräber der IV und V Dynastie, $O B O, 37$. p.121 ff, Göttingen: Freiburg Schweiz.

${ }^{22}$ Smither, P. (1939) op.cit.,p. 34; Spanel, D. (1996) "Paleographic and Epigraphic Distinction Between Texts of the so- called First Intermediate Period and the Early Twelfth Dynasty in :
} 


\section{دراسات في آثار الوطن العزبيء 1}

\section{Commentary}

An Abydos origin is suggested by the name of Amun-Re, king of the gods, and the name of Osiris $h k j \underline{\text { d.t. }}$.

The stela, by design has similarities with the stelae spread out in the New Kingdom ${ }^{23}$, and it comes from the north cemetery of Abydos. $^{24}$ Themes and form which reflect innovations of its top with the Udjat eyes and the $\check{s} n \operatorname{sign}^{25}$. It is certainly worth mentioning in this connection that the making libation on the offering table, together with the addressee gods of the Necropolis ; Wepwawat, Osiris, Anubis and Ptah-Soker-Osiris ${ }^{26}$ would label this stela under the family stelae, ${ }^{27}$ set up at Abydos, whereas, the deceased is usually depicted on its upper part receiving the offerings from his family whom wished him(or $\backslash$ her ) a good resurrection and enjoyment of eternity through the materials of offerings and the powers of those gods of the netherworld. ${ }^{28}$

Manuelian, studies in Honor of William Kely Simpson, vol. II, 766, Boston. see also ; Barta, W. (1968) Aufbau und Bedeutung der altägyptischen Opferformel, 72, 81, 85, 107, Glückstadt.

${ }^{23}$ For more details compare ;Vandier, J. Manuel, I, 2,724-774, II 386-522: Martin, Stele, in: 'Lexikon der Ägyptologie' VI, 1-6.; Stadelman, (1983) Sheintür oder stelen im Totentempeln des AR, Mitteilungen des Deutschen Archäologischen Instituts Abteilung Kairo 39, p.237-241; Simpson, W. (1979) Two Stelae of Overseer of Goldworkers of Amun, Amunemhab at Yale and the Oriental Institute (pls.2-3) in: Bulletin of Egyptological Seminar I, 47-54.

${ }^{24}$ Simpson, W. (1974) The Terrace of the Great God at Abydos: The Offering Chapels of Dynasties 12 and 13, p.13, New Haven and Philadelphia

${ }^{25}$ Stewart, H. (1976) Egyptian Stelae, Reliefs and Paintings from the Petrie collections I, Warminster, , passim; Simpson, W. Two Stelae of the Overseer of Amun, Amunemhab at Yale and Oriental Institute, pp. 47-54.

${ }^{26}$ Mercer, S. (1949) The Religion of Ancient Egypt, passim; London.

${ }^{27}$ Pinch, G. (1993) Votive Offerings to Hathor, Oxford, Griffith Institute, 278, Ashmolean Museum.

28 - The offering formula of this stela contains the material of offerings which the deceased wished to sustain and secure his eternal life. It was believed that the inscriptions and pictures of offerings on the stelae would furnish the dead with all the requisites for their eternal welfare, when, with the lapse of years, the supply of material offerings and the recitations and the ritual performances of the funerary priests had inevitably ceased. Nevertheless, it was felt that in the long run material offerings were the safest means of sustaining the dead, that the spoken was more efficacious than the written word, and that pictures and writings were the last resource. the representation of this document is typical for the period of the New Kingdom. Moreover, its relief contained a personal names, that provides us with evidences of the well known priests 


\section{دراسات في آثار الوطن العربيء}

Unfortunately, the inscriptions appears on this stela, does not help to place it with certainty to which reign. In spite of the cartouche with the name of Thutmosis III, the name of the temple of Thutmosis III, the style and relief are more consistent with those current in the time later than Thutmosis III as illustrated by a considerable numbers of stelae attributed to this period. ${ }^{29}$

The top design of the stela, the women dress and man's bag wig with the exposed ears, occurs most probably during the New Kingdom, help in determining a date for the piece to that period. $^{30}$

The title of its owner as $m n^{r} . t$ wr.t $\check{s}$ d.t- $n \underline{t} r$, which translated as the King's nurse, whom the good god praises, it seems, that, was one of the principal titles of its owner, probably was connected with the title of the great foster-mother ${ }^{31}$.

\section{Conclusion}

This stela, by design, has many of the characteristic features of the usual funerary stelae of the New Kingdom and it comes from the beginning of the Eighteenth Dynasty .Important are in this regard, the stela of Nebet-Kebeny contains names, that provides evidences of the Theban families who lived in this area during the New Kingdom. Concerning the dating of this stela , although it does not seem to be any clear evidence pointing to a precise date for this

at Thebes whom played an important role in the religious life during that period.; see als; Vandier, J. Manuell, op.cit., II, I, pp.507-512; Radwan, A. ( 1987) op.cit. p. 227f.

${ }^{29}$ Frankfort, H. (1928) The Cemeteries of Abydos: Work of the season 1925-26 in: Journal of Egyptian Archaeology 14, ,pp.238 ff ; Munro, P. (1973) Die Spätägyptischen Totenstelen, Ägyptologische Forschungen 25, pl.156, 159 Glückstadt; Vandier, J. Manuel d'archéologie égyptienne 11/1, 498. 502- 5. 519; Gaballa, A. (1979) three funerary stelae from New Kingdom; in: Mitteilungen des Deutschen Archäologischen Instituts Abteilung Kairo 35, pp. 189- 194; Gaballa, A. (1979) false-door stelae of some Memphite personnel, in: Studien zur Altägyptischen Kultur 7, pp.41-52; Radwan, A. ( 1987) op.cit. p. 228 ff .

${ }^{30}$ Hölsher, U. (1954) Post Ramesside Remains, OIP, 66, p. 27; Pfluger, K. (1947) "Private Funerary Stelae of the Middle Kingdom", Journal of the American Oriental Society 67, 127135; Stewart, H. (1976) Egyptian Stelea, Reliefs and Paintings from the Petrie collections I, Warminster.

${ }^{31}$ Variants of this title : Lesko, H. (1982) A Dictionary of Late Egyptian, p. 172 , 174, Berkeley. 
stela except the cartouche of Thutmosis III which appears among its middle part, and the name of Satamun, that was attested during the reign of Amonophis III, the terminology and the various elements in the invocation-offering formula, the elegance in proportions of the persons figures; the circular \& conical loaves and lotus-flower; the type of the offering tables, wigs and garments, together with the libation carried out by its dedicate, all these criteria are quiet clear evidences and could supply us with chronological data for the votive stelae spread out that period of the New Kingdom. According to the aforementioned criteria of dating, this stela could be assigned to the time later than Thutmosis III, ${ }^{33}$ since it exhibits certain features of the stelae it is logical to assign it to the stelae particularly those, which come from Abydos. ${ }^{34}$

From the information given on the stela, a family tree can be constructed, although unfortunately it is still not particularly instructive, and the relationship between the two families depicted in first and second register is not quite clear

\footnotetext{
${ }^{32}$ The use of these elements and other stylistic criteria clearly date the stela to the early part of Dynasty 18, see also: Smither, P. (1939) "The Writing of htp-di-nsw in the Middle and New Kingdom" Journal of Egyptian Archaeology 25. p.34-37; Radwan, A. ( 1987) op.cit. pp. 227-8

${ }^{33}$ Freed, R. (1996) Stela Workshops of Early Dynasty 12, in P. Der Manuelian (ed.), Studies in Honour of. William Kelly Simpson, p. 317, Boston.

${ }^{34}$ Our stela is erected by her son who is giving an funerary offering to his mother.
} 


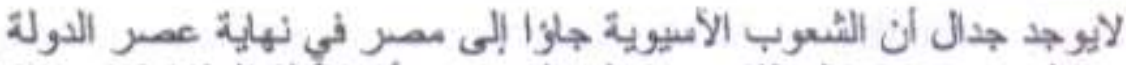

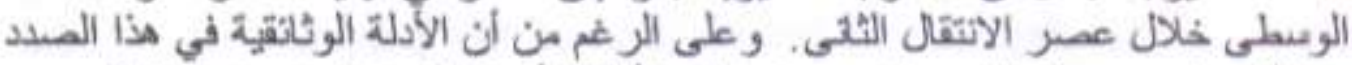

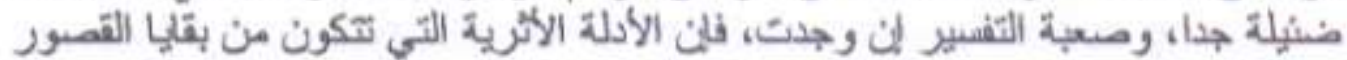

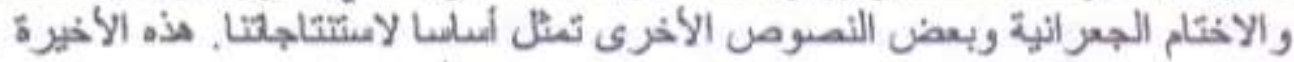

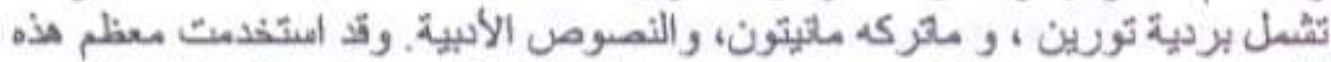

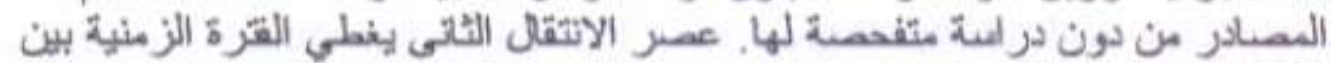

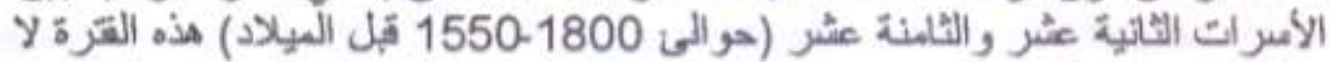

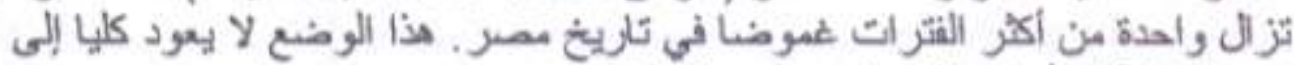

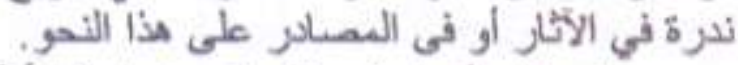

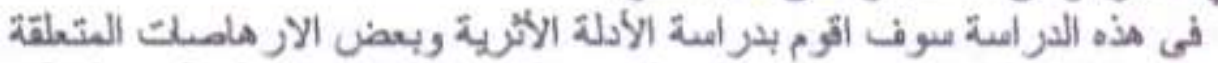

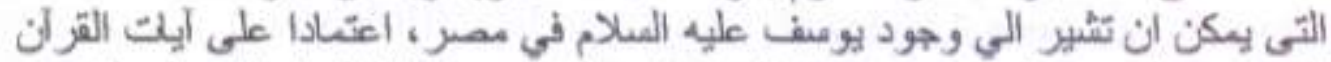

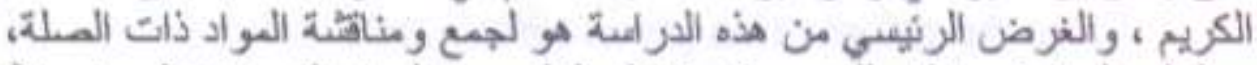

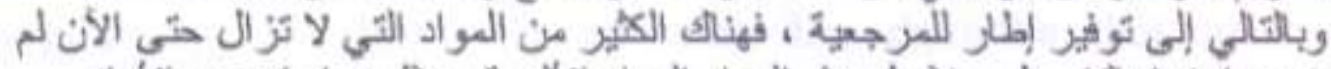

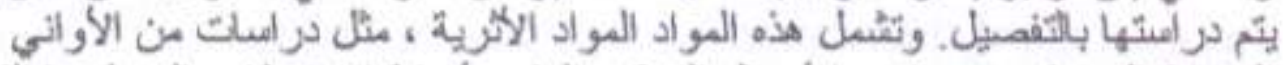

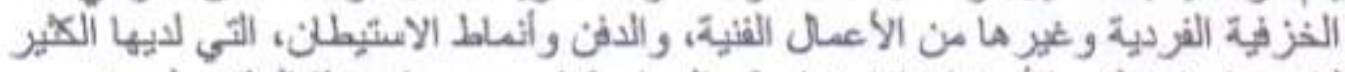

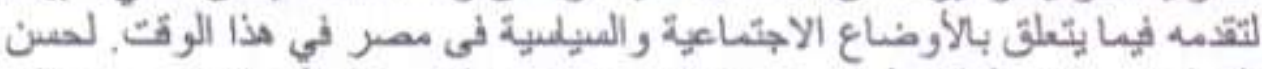

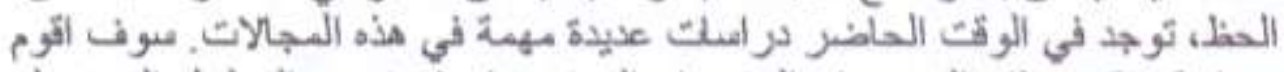

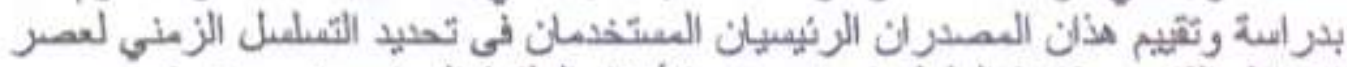

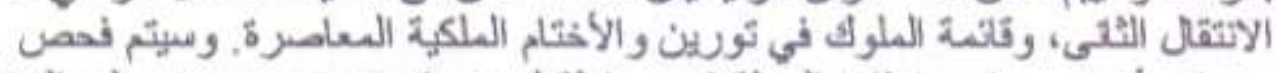

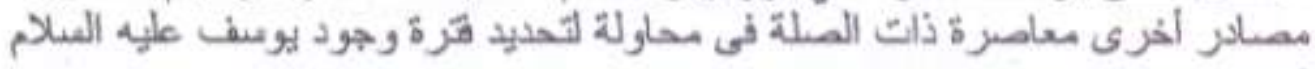
في مصر. 
دراسات في آثار الوطن العربي؛

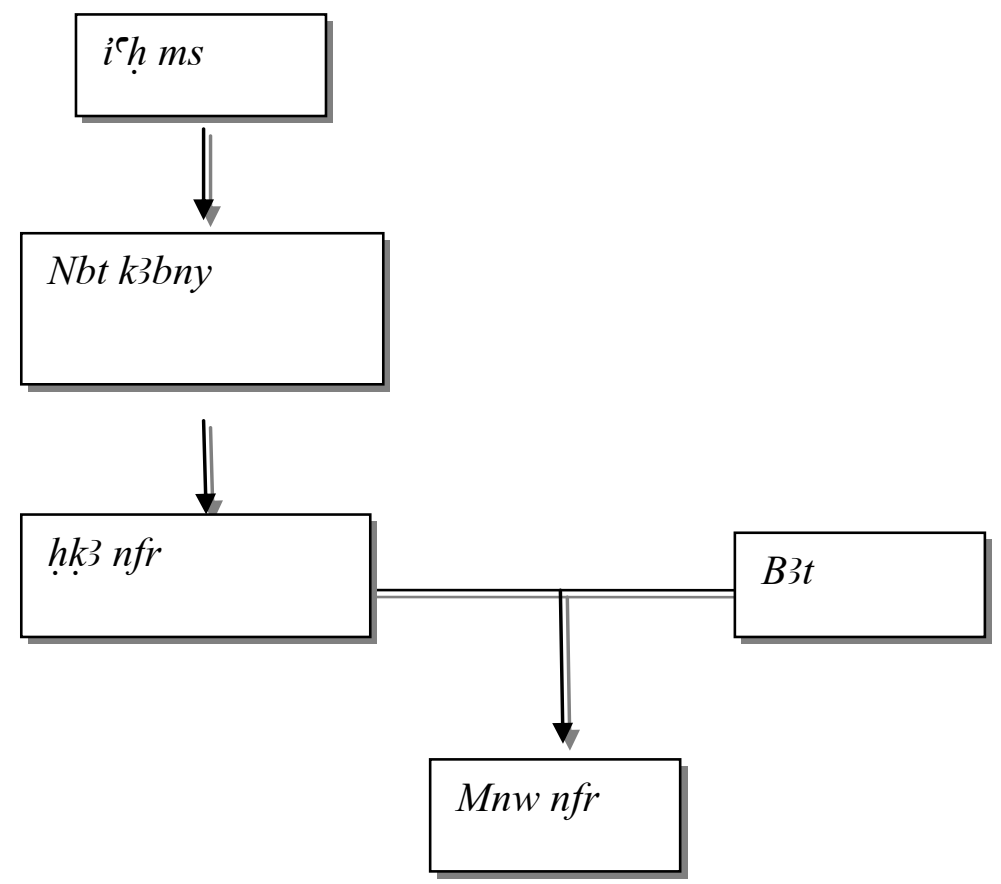

The family of Nbt k3bny

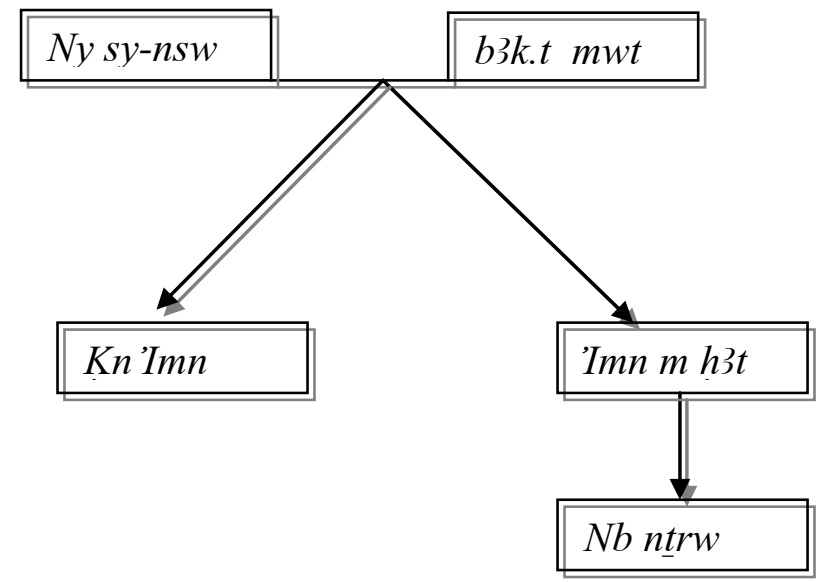

The second Family 


\section{دراسات في آثار الوطن العربيء 1}

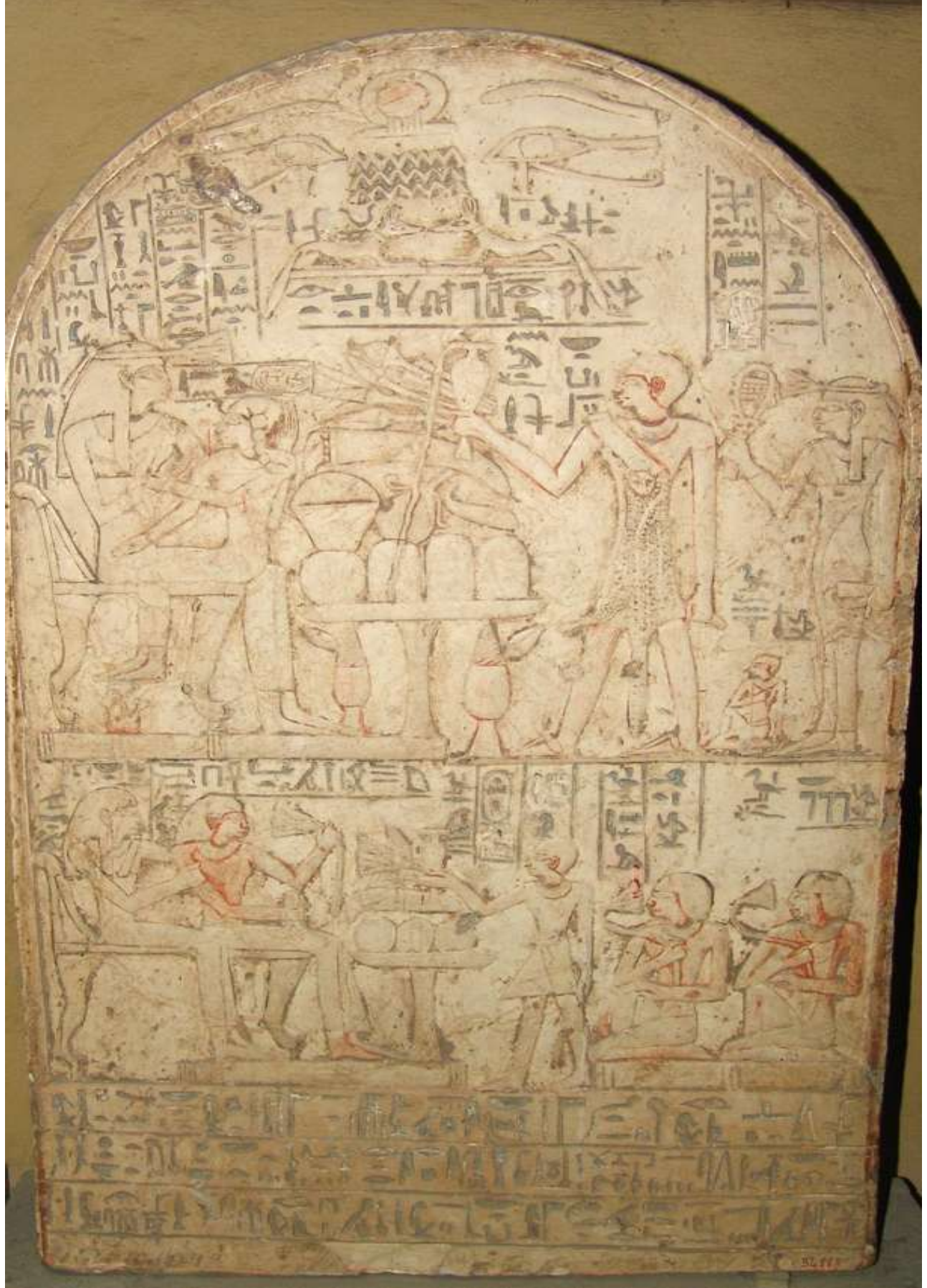

(Fig.1) The Stela of Nebet-Kebeny 